\title{
Practical theology '[re]entering vernacular culture?' New frontiers and challenges to doing theology as life goes on
}

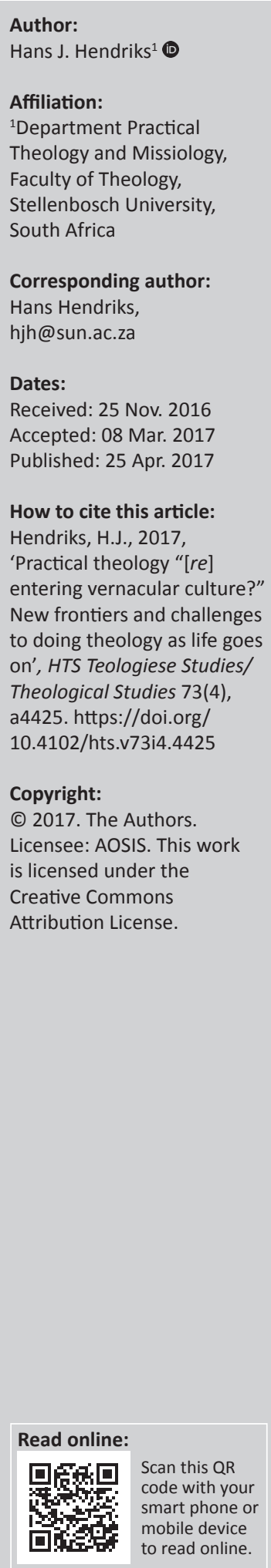

This article critically discusses the necessity for (practical) theology to transform. Taking as a point of departure church historian Andrew Walls' remark: 'Christian faith must go on being translated, must continuously enter into the vernacular culture and interact with it, or it withers and fades', examples from ministry are discussed, specifically from the Dutch Reformed Church. These examples reveal the inability or ability of faith communities to enter vernacular culture and to interact with it. Historical cycles of church growth and decline as outlined by Phyllis Tickle are used to explain the concepts of entering and interacting vernacular culture, and consequently, what it means to 'do theology as life goes on'. The latter refers to more than a rationally controlled process as it is also intimately connected with issues of identity, understanding of the missio Dei and a way of life and discernment that flows from being actively involved in life.

\section{Introduction: On transformation}

Transformation is part of life. Getting bogged down in institutionalism eventually leads to decline and demise. In his discussion of the seven volumes of Scott Latourette's The History of the Expansion of Christianity (1937-1945), Andrew Walls saw the danger of this very clearly. 'The Christian story', he says, 'is not a steady triumphant progression, it is a story of advance and recession' (Walls 2002:12). 'Christian faith must go on being translated, must continuously enter into the vernacular culture and interact with it, or it withers and fades' (p. 29). ${ }^{1}$ His rendering of the growth and decline cycles in Christian history helped Walls to formulate a basic thesis on change and frontier crossing that forms the gist of this article:

There is a significant feature in each of ... [the]demographic and cultural shifts of the Christian centre of gravity. In each case a threatened eclipse of Christianity was averted by its cross-cultural diffusion. Crossing cultural boundaries has been the life blood of historic Christianity. It is also noteworthy that most of the energy for the frontier crossing has come from the periphery rather than from the centre. (p. 32)

Having spent a lifetime teaching Practical Theology, it may be of value to myself and others similarly occupied to reflect on what we are experiencing in our church ${ }^{2}$ and society at present in order to highlight the 'gravity of the shift'. The purpose is to rethink our discipline and to identify pointers toward how it may prophetically serve a much needed transformation process.

However, to even begin such a reflection, one must be aware that one's understanding of theology is crucial to one's hermeneutic, that is, for the way in which one does theology. In my case, Valdir Steuernagel (2003) offers a gripping rendering of the story of Mary, mother of Jesus, as an example of a theologian, of doing theology:

Mary, the theologian that, as a woman, opens her womb to God. Her womb, the deepest place where life is born. A woman who struggles intensively in her search to understand her son and not to experience her faith as despair. A woman who cries in rebellious confusion, but still goes to the foot of her son's cross. A woman who does theology as life goes on. (pp. 100-101)

1.Loren Mead's publications (1991; 1994; 1996), of which the first one was called 'The once and future church, reinventing the church for a new mission frontier', described the same phenomenon very well in what boils down to an ethnographic study of mainline congregations in the USA. Mead's publications therefore call, as Walls does, for a translation of the Christian faith into the vernacular culture of his day, in the USA. Mead's publications therefore call, as Walls does, for a translation of the Christian faith into the vernacular culture of his day,
interacting with it. Walls uses the word vernacular $(2002: 39-40,42-43,87)$ to refer to the importance of ordinary (local) speech, language and culture. Both imply that being part of the local or vernacular life, language and action (culture), it is an essential part of the transformation process. If it does not happen, Christianity gets stuck in institutionalisation and a slow process of decline and death.

2.In my case, I will refer to the Dutch Reformed Church as a way of delineating the subject. 
Practical theology begins as a listening exercise, reflecting on our efforts to understand this God who appears to us, speaks to us and calls us. ${ }^{3}$ The first step in doing theology is to be able to say: 'I am the Lord's servant. May it be to me as you have said' (Lk 1:38). Reflecting on Mary, Steuernagel points out that theology comes at the 'second hour' (2003:103) in reflecting on God's action in our midst and in history. It is, therefore, in a sense 'a womb thing', it is not merely an objective rational exercise, not mere knowledge. Thus, it is practical. It is about being involved, about Christ taking shape in one and about following him (pp. 104-105). Theology is done in visiting others, it is about sharing and discussing and it is about worshipping together? (pp. 105-106). Looking at Mary, one realises that theology is following a path that eventually leads to the cross and salvation. Salvation is not self-salvation, it is about sacrificing the self in serving others, the world, the Kingdom of God (p. 111). If we want to follow Jesus, the cross is inevitable. The self has to die in order to serve the world, to 'let thy kingdom come'.

\section{Doing theology 'as life goes on'}

At any given time, institutions find themselves at different junctures. Compare the phrases used in two requests that were put to the author of this article: The United Presbyterian Church of Southern Africa asked (in August 2016) that their probationers be addressed on the following theme: 'Congregational renewal: the role of biblical leadership and strategic planning in the development of the mission of a congregation'. The Presbyterian Church's roots in South Africa dates back to 1897 when individual congregations formed the Presbyterian Church in South Africa (Bax 2013:143). Words like 'renewal' and 'strategic planning' in the above request reflect an institutionalised era. More about this is discussed later.

An organisation called ALICT ${ }^{4}$ emailed me (18 August 2016) and asked:

We need someone for a session called 'Transformation of the church', that can give a short framework of where the church is and how it can be transformed closer to God's calling for the church. We would like to see or hear of many practical examples that the church can be serving the community and reaching out.

On its website, ALICT succinct account of its short history reads:

In obedience to God's call a unique learning experience for young, innovative and entrepreneurial leaders based on experiential learning started. Beginning in 2004, the first 3-month school was hosted near Cape Town in 2004 and the Institute for Transformational Leadership was born. The Body of Christ needs more Kingdom minded innovators who are able to connect across divides; whether the issue be denomination, culture,

3.When i am using the terminology 'doing theology as life goes on', i am using Steuernagel's discussion of Mary as a practical theologian to define what Heitink (1999:6) put in a more rational way by saying that practical theology as a theory of action 'is the empirically oriented theological theory of the mediation of the action is the empirically oriented theological
Christian faith in the praxis of modern society'.

4.ALICT stands for 'The African leadership institution for community development'. http://www.itl.org.za/ They are a front organisation for the ITL, the Institute fo Transformational Leadership (downloaded 08 Sept 2016). socio-economic class, language, gender, age, race or religion. (http://www.itl.org.za/about-us/) $)^{5}$

A Stellenbosch story, spanning 20 years, illustrates how difficult it is to transform, especially when an institution is within the DNA structures of Christendom. Walls (2002) explains that one should distinguish between Christianity and Christendom:

English has two words: 'Christianity', suggesting a concept, a religious system, a term that can be used in forms of discussion as the formal parallel to other religious systems such as Hinduism or Buddhism, and 'Christendom', suggesting an entity with temporal dimensions, something that can be plotted on a map. (p. 36)

Well-known former Princeton theologian Darryl Guder (1998) defines Christendom as:

... the system of church-state partnership and cultural hegemony in which the Christian religion was the protected and privileged religion of society and the church its legally established institutional form. (p. 6)

Christendom started with Constantine in the fourth century and can be described as the institutionalisation of the Christian faith, making it serve territorially located 'kingdoms' where it often became servant to ideological motives of the state (Mead 1991:13-22). Biblical Israel always struggled to understand that it was to be a blessing unto the world (Gn 12:1-3). Dutch Reformed Church (DRC) congregations, like most mainline denominations, have such a Christendom paradigm in their theological DNA. A sad and obvious example of this phenomenon was the theological support given by the DRC to the apartheid regime and ideology (cf. Kinghorn 1986; Naude 2010:149-165).

In 1996, the DRC Presbytery of Stellenbosch realised that the 'market share' of DRC congregations was shrinking and that they simply did not communicate with or appeal to a growing group of younger people in the town (Ring van Stellenbosch 1997b). A special meeting of the Presbytery (Ring van Stellenbosch 1997a) approved the establishment of a new congregation (amongst several other bold initiatives). The church board of the congregations that had to launch the new congregation soon lost momentum. It was clear that taking bold steps were not as easy as was imagined! This left a well-organised and networked group of younger people in town frustrated, but not for long. The Apostolic Faith Mission (AFM) church appointed a young, energetic, talented and thoroughly contemporary pastor. Most of us who called the special meeting of the Presbytery, saw the hand of God in this and supported his ministry. Church attendance at the new congregation, soon officially disaffiliated from the AFM, grew in leaps and bounds. Ever bigger venues were needed for worship services. The congregation eventually settled in the school hall of the

5.Since 2004 , young African leaders from all walks of life representing more than 50 African nations attended the three-month programme focused on leadership has 30 attendees. 
Paul Roos Gymnasium. The congregation changed its name to 'Stellenbosch Gemeente' (Stellenbosch Congregation SG) but was popularly referred to with reference to its pastor, as 'his Church'. It was 'a hit' in town and younger people flocked to the worship services and communication style which they found fresh and exhilarating. This had a marked effect on the well-known DRC 'Studentekerk' (Student congregation). Soon attendance at the Studentekerk usually filled to capacity during evening services dwindled to about $25 \%$ of what it was previously (cf. Van Zyl 2008).

In 2007, SG began experiencing problems and the author was consulted in to address these. Willow Creek Community Church $^{6}$ served as role model for SG. ${ }^{7}$ In retrospect, the problem was one of leadership and church model. The pastor was perceived by some to be acting more like a CEO. His strongest support came from the prominent members of SG's Church Board who were powerful CEOs in their own right. Concerns were raised that the congregation was run like a business with values like effectivity and success held in high esteem, and that worship services were staged with single-minded dedication to quality and effect, to please the audience. It was a purpose-driven church, theoretically missional, but in practice portraying capitalistic values. Staff relations were tense and staff often left traumatised by unresolved tensions. SG's board had to make tough decisions. The founding pastor decided to move on.

A remark by Pulitzer Prize winner Tom Friedman in The world is flat (2007:96) helped the SG Church Board to diagnose the problem: 'Our communication infrastructure has taken only the first steps in this great shift from audience to participants, but this is where it will go in the next decade'. The new board of SG spent 2 years (20102011) reading Philippians 2 whenever it met, using the socalled dwelling in the Word way of reading, reflecting and sharing (Ellison 2009; Nel 2013; Niemandt 2010:404-407). It helped members to grow into a new ethos. Slowly new values emerged. The abandonment of the dream of building a costly multi-purpose church centre was one example of this. The focus of the congregation was changed from being 'eietyds' [contemporary] to lead " $n$ lewe wat iets beteken' [a significant life]. The focus shifted to empowering members to be participants, to be light and salt wherever they are. Missional theology now drives the congregation in the sense that it focuses not on itself, but on the world. This required a different leadership style as well as a different way of congregational communication. What occurred in SG was a reflection of Friedman's prophetic

6. Willow Creek Community Church (or simply Willow Creek Church) is an American non-denominational and multi-generational Evangelical Christian megachurch located in the Chicago suburb of South Barrington, Illinois. It was founded on October 12, 1975, by Bill Hybels, who is currently the senior pastor. The church has churches in the United States (this ranking includes multi-site churches). (https:// churches in the United States (this ranking includes multi-site
en.wikipedia.org/wiki/Willow_Creek_Community_Church).

7.'Willow Creek repents' a most interesting article that appeared in Christianity Today (http://www.christianitytoday.com/pastors/2007/october-online-only/willowcreek-repents.html ) and echoes the same type of problem that SG encountered. insight in the deep changes in our society. He calls the principle 'uploading's ${ }^{8}$ and defines it as:

The newfound power of individuals and communities to send up, out, and around their own products and ideas, often for free, rather than passively downloading them from commercial enterprises or traditional hierarchies, is fundamentally reshaping the flow of creativity, innovation, political mobilization and information gathering and dissemination. It is making each of these things a bottom-up and globally side-to-side phenomenon, not exclusively a top-down one. ... Uploading is, without doubt, becoming one of the most revolutionary forms of collaboration in the flat world. More than ever, we can all now be producers, not just consumers. (p. 95)

It is worth the trouble to visit the website of Stellenbosch Gemeente to see how the above changes are reflected. Usually worship services portray an 'uploading' style. 'Uploading' is illustrated in, for instance, the 14 August 2016 service (http: / / www.sg.org.za/preek-sondag-14-augustus/). During the latter service, the pastor conducted an interview with a congregant. The congregant shared how discernment and innovate ideas 'from below' earmark the story of the congregation. He then put the following question to the congregation": 'If the whole congregation could hear your voice, what would you like to say to us?' Of all present, 51\% responded in 350 written answers. These responses were analysed, discussed, reported to the congregation and acted upon. The whole process led to a number of new initiatives in which the church board and staff act as facilitators only and in no way try to control or guide initiatives.

Any road to deep transformation is a many-staged journey. Sacrificing institutionalised Christendom identity that for long provided security to its members is difficult. In fact, growing into a new identity where one is challenged to move out of comfort zones on a 'Matthew 28:16-20 journey' requires conversion. However, if one wants to follow Christ, 'kenosis style $^{\prime},{ }^{10}$ this is what it implies. It is very difficult to do this within denominational structures that inhibit 'thinking-out-ofthe-box initiatives'. In this sense, SG was fortunate, not being bound to any established institutional or denominational structures. It could do what it was led to do without a 'big brother' keeping it within long-established Christendom boundaries. ${ }^{11}$ The same principle of freedom to experiment applies to church planting (cf. Dennison 1999; Mead 1994:72-85; Moore 2002). Walls (2002:67-68) points out that Judaism made proselytes requiring people to adopt Jewish customs (such

\footnotetext{
8. Be reminded of what church historian Walls (2002:32) said (quoted above): 'It is also noteworthy that most of the energy for the frontier crossing has come from
the periphery rather than from the centre'. Actually, 'uploading' as described the periphery rather than from the centre'. Actually, 'uploading' as described here, repeats in other words the hypothesis of Walls used in this article.

9.What happened in the congregation, the developing ethos, is well described by the remark of Leonard Sweet (2000) that the postmodern generation can be described with the acronym EPIC: experiential, participatory, image-driven and connected.

10.(Gorman 2009) defines kenotic: Phil 2:6-8 reveals the narrative identity of the Messiah Jesus as one who possessed equality with God ... did not exploit it for selfish advantage ... but, like a slave, emptied himself in incarnation and humbled himself obediently ... such that the result was death - death on a cross. ... Christ's divinity, and thus divinity itself, is being narratively defined as kenotic and cruciform in character. (p. 25)

11.Mead (1996) suggests: 'Transfer the ownership of the church' (pp. 1-15), then 'Find new structures to carry our faith' (pp. 16-31) and adjust the role of the judicatory (1994:72-85).
} 
as circumcision) and culture. However, 'denominational or ideological proselytes' seldom impact culture, and they are simply assimilated into an existing culture. At its heart, however, to be Christian means turning to Christ. It implies conversion and as such breaking with many cultural practices as the astonishing story of Acts 15 testifies. During the first years of its existence, SG was an upbeat, culturally pleasing, modernised church, but then it was challenged to ask itself whether it was a missional church, one whose members follow Christ in this world and whose values and lifestyle reflect his and differ from contrary contemporary cultural norms.

Another example of such a struggle towards transformation in doing theology as life goes on may be illustrated within the DRC itself by looking at the way many small, rural congregations are struggling. The DRC General Synod report on small congregations is worth reading and is based on thorough research (Handelinge Algemene Sinode 2011). An HTS article was based on the research and its results (Hendriks 2012). Du Plooy's (2013) research in the Karoo replicated the findings. Most DRC members and surely most (rural) congregations are stuck in the institutionalised Christendom paradigm as explained above. These congregations are territorial, cultural and denominational with political and economic values determining its membership and ministry (cf. Mocke 1994). A small rural community does not have the financial resources to have more than one congregation with a paid pastor. One usually finds either a few minute congregations without fulltime pastors or with only one pastor serving in the congregation which only the most affluent group can afford. More often than not this pastor has to dance to the tune of those members who keep the congregation financially alive! Peens' study (2011) of the small rural community of Marken in the Northwest Province of South Africa shows how this dilemma may be overcome. The pastor (Peens) exposed the small congregation of less than a 100 members to missional theology. As a consequence, a number of politically right wing members resigned and joined the racially very conservative Afrikaanse Protestanse Kerk. The pastor could, however, not be persuaded to change direction - not even financial threats were successful as he is also a farmer in the area and declined any remuneration from the congregation. Thus, a shift in identity occurred in the congregation and its members started to serve their community - which is $99 \%$ black, rural and poor. They became a valuable asset to the broader community and received the respect, support and cooperation from the majority of people in that area.

The above are simply two local examples of how new forms of church and ways of being church are developing in our midst. Another good example is called 'The World needs a Father' (TWNAF). ${ }^{12}$ The movement started in the Cape. On its website, one reads:

'The World Needs a Father' (TWNAF) came into being in February 2011 and has as main focus the preparation and training of able men who will train others. Boys need to be prepared for

12.Traditional family values are globally in flux (Adedibu 2009:17-20, 2012:173-174) (http://www.theworldneedsafather.com/). Information of the situation in the USA (http://www.theworldneedsafather.com/). Information of the situation in the USA
can be found at: http://www.fatherhood.org/fatherhood-data-statistics and sites like https://www.fatherhood.gov/ manhood, young men to be fathers one day and fathers need help to provide proper leadership to their families. Fathers must be restored to their God-given place as servant-leaders of their families.

Few would argue that globally marriage and family life are under extreme stress and that it is especially men who struggle to understand their biblical role as husbands and fathers. In TWNAF, one finds something that started as a local ministry and within 5 years expanded to 37 countries with a basic textbook translated in 19 languages! (cf. Carstens 2014) Especially in the Far East, the growth of this ministry has been astonishing. In Sri Lanka, the Philippines and China, the movement is spreading like wild fire. The basic method is simple: it requires applying discipleship principles and training mentors who can address a very deep need. Financially, there are no huge foundations sponsoring TWNAF. It does not want to become an organisation but is focused on being a movement. It shares a biblical vision and is not set on making proselytes as it moves from country to country and culture to culture. This enables local leaders adapt it to own contextual needs. In this movement, one can see the truth in what Walls (2002:29) observes, namely that 'Christian faith must go on being translated, must continuously enter into the vernacular culture and interact with it, or it withers and fades'.

However, to a large degree, the sad part of the story of Christendom is that in most cases, churches die and church buildings remain as relics of a long-gone era (Walls 2002:66). But, this need not be the case and this has much to do with transformation.

Over the past years, several theologians have written on the issue of transformation. Hendriks (2009) discusses identity transformation in the DRC. Niemandt $(2007 ; 2013)$ wrote extensively about it and challenged the church in South Africa toward a new dream and a new leadership paradigm. Marais $(2007 ; 2010)$ made a valuable contribution in helping transform the decision-making process in the DRC from debate to discernment. These contributions are part of the phenomenon which sees the global missional church movement is taking up the challenge of transformation (Keifert 2006). But, as was seen, this is not transformation for its own sake. If we want to do theology, as Steuernagel writes, in the way Mary did, as life goes on, we need to prophetically understand and acknowledge the dilemma that faces us. This is about much more than keeping a religious organisation afloat by market analysis and strategic planning. The biggest challenge is to take the first obedient step and practically engage in a journey following Jesus, being open to the guidance of the Helper, the Holy Spirit, relying on the love and support of the Father.

For the church to embark on this journey, it will be worth our while, even necessary, to familiarise ourselves with the emerging new globalised world. This may help us to understand and explain the growth and decline cycles in history and to analyse it and to see how it affects us (more on 
this in 'Five episodes of doing theology as life goes on' section below). It will help to understand the vernacular cultural changes of our local context. For us 'understanding' (rational thought) comes easy. How do we move from a fixed rational strategic planning and goal setting paradigm to 'uploading' where we are open to frontier crossing following the leads that come from the periphery rather than from the centre? How do we do theology as life goes on?

\section{An emerging new world for the Dutch Reformed Church}

The older pastors in the DRC will remember the hierarchical power structures that literally controlled ministry, from catechetical material to the programmes one had to follow. The DRC's struggle to denounce apartheid (De Gruchy 2004:67-84; Kinghorn 1986) went hand in hand with a struggle on congregational level to discover the church's true identity. The apartheid system kept a racially divided organisational structure in place that wielded a lot of power. Being a DRC member played an important role in securing status and influence. ${ }^{13}$ When the ideology behind the system was denounced, the Church's societal influence and power began disintegrating and it began losing members (cf. Hendriks \& Erasmus 2005). Congregations struggled to understand the implications of the transformation process into the new political dispensation.

In the late eighties and nineties, DRC congregations realised they faced a new reality, a new world (Naude 2010:149-165). They had to learn to think for themselves and to interact with the vernacular culture. Apartheid was collapsing and the Church that played a key role in keeping it intact faced the challenge of acknowledging its mistakes and to reorientate and find a new identity and mission. Those members of the church who belonged to it for the sake of social status and benefits began leaving. Membership numbers, therefore, started declining (Hendriks \& Erasmus 2005). Measures were taken to address the dilemma. One such move was to introduce Gemeentebou in theological education. In 1985, the author was called to a chair called Gemeentebou ${ }^{14}$ at the Faculty of Theology at Stellenbosch. In the same year, a very popular new Master's in Theology programme in Gemeentebou was introduced at the Faculty. Nel (1994) and Hendriks (1992) published textbooks on the topic. Eventually, Gemeentebou evolved to the present focus on missional theology (Sheridan \& Hendriks 2013). A 2013 report tabled and accepted by the General Synod of the DRC proves that a very deep theological transformation is taking place in the DRC (Algemene Sinode 2013:199-215). Congregational leadership, however, holds the key to whether the identity of the church will be transformed in a missional direction.

13.The sermons and thoughts of Jaap Durand are a valuable portrait of the struggle against the apartheid ideology (Du Toit 2014).

14.Church growth is not a good translation because of the connotation to that movement in the USA (McGavran 1980). The DRC never took that option. We wer closer to the 'Gemeindeaufbaus' movement in Germany (Schwarz \& Schwarz 1984) or 'Gemeenteopbouw' in the Netherlands (Bons-Storm 1987; Goedhart 1984).
Walls's words (2002:29) 'Christian faith must go on being translated, must continuously enter into the vernacular culture and interact with it, or it withers and fades' guide the quest towards missional transformation. My recollection of how this happened in the DRC on a congregational level was that it occurred in the wake of countless church board meetings, seminars, sermons, conferences and consultations that focused on, amongst others, ecclesiology. Avery Dulles' book (1985) on the models of the church was extremely helpful in this regard and, soon afterwards, David Bosch's Transforming mission (1991) helped us to discover a missional ecclesiology and theology. The second and third parts of Transforming Mission outlined the historical paradigms of mission (pp. 181-510). Since many of us were born and bred in a rational paradigm, we needed a hermeneutical key and intellectual guidance to help us on the road to transformation and rediscovering the way to do theology 'as life goes on'. Historical cycles in church and theology became clear and a hermeneutical approach in dealing with transformation helped us in doing theology 'as life goes on'. The latter required the acknowledgement of the interplay between Word and World, between the Bible and context and at least on an intellectual level we could start to translate Christian faith to daily life and vernacular culture. Someone like Patrick Keifert (author of We are here now, a new missional era, 2006) visited South Africa and through his writings he played an important role in helping us do theology 'as life goes on'. Of course, there were many others that helped us on this journey to whom we will be eternally indebted.

But what exactly does doing theology as life goes on imply and where does this leave us today? This is reflected in the next section with reference the so-called five episodes of doing such theology as explained by Phyllis Tickle.

\section{Five episodes of doing theology as life goes on}

In her work The great emergence (2008), Phyllis Tickle describes four 500-year cycles in the history of Christianity, starting with the ascension of Christ. Her motive is to explain the enormity of the present transition that is taking place in our world and how important it is to understand what is happening to us. Tickle does not mention Walls, but she makes the same point as him when he says that 'Christian faith must go on being translated, must continuously enter into the vernacular culture and interact with it, or it withers and fades' (Walls 2002:29).

Space prevents going into the detail of Tickle's argument, but even a cursory account may offer guidelines in the quest to do theology as life goes on.

\section{The first three cycles}

In the first 500 years of its existence, Christianity was pretty much an unregulated movement, though it can be described as a Great Transformation (Tickle 2008:120), shedding its Jewish exclusivity. Rodney Stark's (1997:6-7) study on why the 
Jesus movement had such an impact shows that the movement started with about 1000 members in the year 40 and by the fourth century totalled close to 34 million people or $56 \%$ of the population of the Roman Empire - a growth of $40 \%$ per decade! Stark's makes a significant remark on page 20:

The basis for successful conversionist movements is growth through social networks, through a structure of direct and intimate interpersonal attachments. ${ }^{15}$

To further summarise Stark's view would be by saying that the growth of Christianity was also due to:

1. The Christian life style was different to that of the world.

2. Christians cared. They helped one another and loved one another.

3. Christians' marriage and family life gave security in a chaotic world.

4. Racism, classism and sexism were addressed in Christian circles.

5. Christians were hard working and dependable.

The sad truth is that, when Christianity became co-opted by the Roman Empire as its official religion, a mutual beneficial marriage between church and state took place, the church was institutionalised and Christendom was born. Slowly the church lost its biblical or missional character (Mead 1991:8-29).

The second 500-year cycle was typified by Pope Gregory the Great (Tickle 2008:21-26). Rome was invaded by barbarian hordes in 410. In 480, the Roman Senate 'finally and officially disbanded itself' (p. 23). In those chaotic times, Gregory, born in 540, became pope in about 590. He was called 'The Great' because of the brilliant way in which he ended the chaos left by the collapse of the Roman Empire. He 'guided Christianity firmly into monasticism that would protect, preserve and characterize it during the next five centuries'. In Walls' (2002) words:

... monasteries were a cultural coherent way for those who wished to be radically Christian to imitate the lifestyle of Jesus and his apostles. Further, they were alternative communities for those who saw no way of living a consistent Christian life amid the demands of kinship and vassalage and the pressures of a violent society ... (p. 16)

The third 500-year cycle was introduced by the Great Schism of 1054, when the Patriarch of Constantinople and the Pope of Rome excommunicated one another on doctrinal differences regarding the Holy Spirit and other issues. Although these issues make little sense today, in the political and economic context of the time, it did (cf. Tickle 2008:20-21). The result of the schism was a division between Western, Eastern and Oriental Christianity (Coptic, Ethiopian, Armenian \& Syrian Orthodox). In many ways, it was also a time of decline for Christianity as the countries where it had its roots (Palestine, North

15. Compare this statement with that of Castells' emphasis on the role of networks in the globalised world (discussed in 'The fifth cycle: "The Great Emergence"' section) and Niemandt's (2013:146-156) emphasis of the relationship between missional leadership and networks.
Africa, Eastern Europe) were conquered by the Islamic Ottoman Empire. In 1453, the Ottomans captured Constantinople. Thousands of Greek Orthodox scholars, traders and intelligentsia fled to Europe.

\section{The fourth cycle: The 'Great Reformation'}

The fourth 500-year cycle was symbolically introduced on 31 October 1517 when Martin Luther nailed his 95 theses to the door of the All Saints Church in Wittenberg, Germany. Tickle (2008:13 following) calls the fourth cycle the 'Great Reformation'. The 500 years between Luther and the end of the millennium in 2000 had an enormous influence on our present globalised world. It is crucial to understand the Reformation and the 'DNA' of Protestantism that took shape in this cycle. As always, context interacted with how the Bible was read and what people believed. Some of the major traits that played a role were:

- The capture of Constantinople by the Ottoman Turks in 1453 resulting in 'thousands of Greek Orthodox scholars, traders and intelligentsia' fleeing and taking up residence in Europe and the fact that '... they brought with them the spectacular scientific and mathematical knowledge of the Arab/Islamic culture ...' (Tickle 2008:47).

- The big question of the Reformation was: 'How is one saved?' (Not by Mary, nor by the 7 sacraments nor by selling of indulgences [forgiveness] from sins).

- The printing press was discovered, the Bible translated and common people were taught to read and write catechisms played a big role; Sunday schools educated the working classes. It was an intellectual quest to convince people of the truth of the Bible over and against the dogma of the Roman Catholic Church. However, the Reformation had not only ecclesial consequences, but also social, political and economic implications as religious wars erupted all over Europe.

- Protestant clerics were trained at Universities in order to lead the intellectual battle against the Roman Catholic Church. Doing theology became intellectualised and was strongly influenced by the rational ethos of universities.

- Natural Sciences developed. Descartes' motto cogito ergo sum expressed the basis of the Western Enlightenment and eventually the thought patterns of modernity. Individualism and rationalism pushed religion to the private spheres of life.

- The nation-state developed and, in Tickle's account, cash became powerful and capitalism developed. Colonialisation, as an economically politically driven process, co-opted the church in all its ventures. The Christendom paradigm as a territorial venture with its close cooperation between the church and state was strengthened.

- Boisterous optimism prevailed in the West. The conviction was that all problems can eventually be solved through science and concerted effort. Logic, rationalism and the individual's ability to use it to his or her benefit became culturally engrained. 


\section{The fifth cycle: 'The Great Emergence'}

Around the year 2000, we enter what Tickle (2008) calls 'The Great Emergence': 16

... about every five hundred years the empowered structures of institutionalized Christianity, whatever they may be at that time, become an intolerable carapace that must be shattered in order that renewal and new growth may occur. (p. 13)

Tickle's observation above concurs with both the central thesis of Latourette's six volumes on the history of Christianity (1937-1945) and Walls' formulation (2002:29) has been repeatedly referred to thus far, namely that 'Christian faith must go on being translated, must continuously enter into the vernacular culture and interact with it, or it withers and fades'. But, what brought this transition about?

In short, explanations for the end of the previous era are, first, that faith in Descartes' rationalist axiom proved to be wholly inadequate and the two foundations of that era, rationalism and individualism started disintegrating (Tickle 2008:71, 160). Similar to the exposure to Aristotle and the intellectual heritage of the Arab or Islamic culture after the fall of Constantinople in 1453, Einstein's 1905 'special theory of relativity' and Heisenberg's 'uncertain principle' broke the hegemony of absolute knowledge and rationality. ${ }^{17}$ Knowledge in the 'natural sciences' was no longer seen as absolute. In fact, it would seem that the words of 1 Corinthians 13:9 'We know only in part, and we prophesy only in part' became accepted again in intellectual circles.

Similar to the disillusionment during the Great Reformation era with its perpetual wars and debates among Christians, another kind of disillusionment developed towards the end of that era. The world began to realise what colonialisation did to many cultures and people. People were (once again) stunned by terrible, now 'world' wars, the killing and devastation it brought about, the genocides that accompanied it, nuclear arms and the advent, as never before, of a divide between rich and poor that new liberal capitalism was causing (Piketty 2014).

One of the earliest signs of the dawn of a new era was the birth of Pentecostalism in 1907 onwards, in the wake of the famous Azusa Street Revival (Cox 1995:45-78; Tickle 2008:83-85). Cox remarks:

My own conviction is that Pentecostals have touched so many people because they have indeed restored something. But they have done it in a very particular way. They have enabled

16.A small 'gem' that also outlines our time and its challenges is Giddens (2002): 'Runaway world, how globalization is reshaping our lives'. Philip Jenkins's work in describing the southern shift of Christianity and the way it is taking shape, is also of crucial importance for this topic (2002; 2006). Adedibu's (2012) narrative of the Black Majority Churches in Britain is a fascinating account of the influence of global migration and how it affects cyclical church patterns. His summary of the emerging trends (2009:7-23) and understanding times and seasons (pp. 24-46) is excellent and very helpful.

17.'The uncertainty principle also called the Heisenberg Uncertainty Principle, or Indeterminacy Principle, articulated (1927) by the German physicist Werner Heisenberg, that the position and the velocity of an object cannot both be measured exactly, at the same time, even in theory. The very concepts of exact measured exactly, at the same time, even in theory. The very concepts of exact
position and exact velocity together, in fact, have no meaning in nature'. http:// abyss.uoregon.edu/ js/21st_century_science/lectures/lec14.html countless people to recover, on a quite personal level, three dimensions of this elemental spirituality that I call 'primal speech', 'primal piety', and 'primal hope'.

Primal speech: In a world where the cognitive grids and perceptual barriers are drawn in cold and clear logic, people need to get in touch with the supernatural, with a God who can relate to them and with whom they can relate, even if words cannot be found to express what is in the heart;

Primal spirituality: Refers to signs and wonders and the recovery of primal piety. The Pentecostals, almost by accident it seems, found a way: They rebelled against creeds but retained mystery. They abolished hierarchies but kept ecstasy. This happened in the worship of those who had to face the new realities of cities being dislocated from their rural lifestyle and family.

Primal hope: Pentecostalism became the global vehicle for the restoration of primal hope in a century with two world wars, a holocaust, the first nuclear bombs, a cold war, innumerable atrocities, and the growing economic disparities illustrated by the growing gap between rich and poor. Eschatology, not only distant, is a reality with Pentecostalism. Music carried their message! (pp. 81-82)

A third explanation for the transition to a new era is the advent of information technology. Similar to the discovery of the printing press in the previous era and subsequently to the emphasis on the doctrine of the priesthood of all believers (Tickle 2008:56, 107), information technology (Tickle 2008:103 following) and the internet brought knowledge and information to ordinary people as never before. Networks formed and opened a new dimension of community. In fact, this phenomenon was and remains so significant, it may be called the cradle of the Great Emergence.

In this regard, the trilogy of the sociologist Manuel Castells on 'The information Age: Economy, Society and Culture' is of great help (1996; 2000; 2004). In his 'Power of Identity' (2004), Castells offers two observations that explain the new world: First, power has shifted from Macht to Mind or, in other words, from physical power to information (2004:424-425). Tickle (2008:51-52, 106-107) called this the transition of power from 'blood' (i.e. monarchies, landlords, elite in the first three cycles) to cash (in the fourth cycle giant economic changes took place $)^{18}$ to information - the Internet.

Castells' second observation concerns identity formation (2004:6-12). What distinguishes the Great Emergence from all previous cycles is that those who controlled the formation of identity (i.e. the way people think, their values and how they see themselves) could no longer do so. Monarchies, capitalists, nation states and patriarchalism ${ }^{19}$ are all in the process of losing power. Castells distinguishes three forms of identity formation: legitimising, resistance and project identity formation:

Legitimizing identity formation. For millennia the latter was the default system of identity formation. It occurs top down

18.Around 1500, the rise of an entrepreneurial middle class took place and capitalism eventually developed. In time, this led to the demise of the nation state and globalisation (Castells 2004:303-366).

19.I found Castells' discussion of patriarchalism (2004:192-302) extremely helpful. It gives the contextual background to a movement like TWNAF that was discussed above. 
when those in power by word and deed tell others who they are, what they should think and what they should do. It is all about controlling the minds of people. This process was enforced, in Tickle's words, by blood (status) or by physical and economic power and superiority. ${ }^{20}$

Resistance identity formation is generated by those actors who are devalued/stigmatized by the logic of domination. They form communes or communities that resist unbearable opposition/ oppression and that build upon already-existing identities defined by history, geography, biology, belief, race/ethnicity, etc. It creates, in other words, a defensive identity.

Project identity is formed when social actors build a new identity that redefines their position in society and, by doing so, seek the transformation of the overall social structure. Two examples are feminism and the ecological movement. This identity produces subjects who pursue a truth or a dream that creates hope and brings justice, something which is understood to be worth living and dying for. (p. 8)

When information became freely available to ordinary people and they were able to pursue new dreams and alternative realities, they started communicating and organising in pursuit of justice and hope, they networked. Castells calls our society the network society. These new networks are challenging the powers to be. In his classic 2012 (revised 2015) work, Networks of outrage and hope, social movements in the internet age, Castells describes the recent Egyptian Revolution (pp. 57-84), the Arab Uprising (pp. 95-110), the Indignadas in Spain (pp. 113-147) and the Occupation of Wall Street (pp. 159-201), after which he analyses the phenomenon (220 following). He shows how networks are where identity formation takes place. It implies a slow but a definite power shift taking place influencing people, social institutions and culture. It is related to what earlier has been called uploading (Friedman 2007:95).

All of the reflections and examples above are signs that the world is changing into what some call a postmodern one. Part of this is a call for 'out with the old and in with the new'. Examples of the old mentioned being the singular emphasis on rationality and individuality, the new: new forms of communication, new forms of identity formation, of perceptions of authority and truth, new communities, and also perhaps new ways of being church. In fact, metaphorically speaking, it seems a global jumble sale is on hand, in society as well as in the church!

Regarding the church, one of the early prophets that saw the new era coming, Brian McLaren, remarked on this in the introduction to The church on the other side, doing ministry in the post-modern age (2000):

If you have a new world, you need a new church. You have a new world. (p. 11)

In Everything must change, Jesus, global crises and a revolution of hope (2007), he gives a parallel description to that of Tickle in

20.Castells in his 2004 conclusion says it well: Mainstream churches, practicing a form of secularized religion dependent either of the state or on the market, lose much of secularized religion dependent either of the state or on the market, lose much
of their capacity to enforce behavior in exchange for providing solace, and selling of their capacity to enforce behav
heavenly real estate (p. 419). her two works $(2008 ; 2012)$. And, to once again return to Walls' (2002:29) thesis, the cycles as described above should lead one to heed his warning that 'Christian faith must go on being translated, must continuously enter into the vernacular culture and interact with it, or it withers and fades'. Thejuxtapositioning of the basic epistemic assumptions and hermeneutical keys of the cycles before and after 2000 together with descriptions of the differences in contexts helps one to see a picture that makes sense. Tickle (2008:27-29, 104-107) often remarks that each cycle made a lasting contribution to church and society. One example she mentions is that the Roman Catholic Church did not disappear after much of its theology was part of its current 'rummage sale'. She describes how it adapted with reference to the current and previous Popes. Benedict $X V I^{21}$ is a German native. Pope Francis ${ }^{22}$ was born in Argentina. Pope Francis is at home and leads in the new paradigm or cycle helping the Roman Catholic Church to enter into the vernacular culture and interacts with it. Rationality and logic will not disappear after its overindulgence during the Enlightenment cycle; it still has its place, but in a broader and more profound framework.

\section{Doing theology in a new key ... as life goes on}

Bosch (1991:349-363) describes the postmodern paradigm, calling it an Emerging Ecumenical Missionary Paradigm (p. 368 following). He explains the epistemological break with the Enlightenment in detail (pp. 423-425) and calls the emergent theology contextual, being done 'from below', 'its main source (apart from Scripture and tradition), is the social sciences, and its main interlocutor the poor or the culturally marginalized' (p. 423).

Interdisciplinary enquiry indeed serves as a new key to doing theology today. In this article, the work of sociologist Castells helped to explain how the world is changing and why. In almost all other literature cited above, the authors were concerned that the economy and capitalism, on the one hand, and democracy and the functioning of the nation state, on the other hand, are points of profound concern. Piketty's Capitalism in the Twenty-First Century (2014) serves as a case in point. As such, it is not only the church that is challenged to enter vernacular culture, interact with it and translate itself to serve the new world. It is a mutual challenge as it also applies to other social actors. Thus, theology can become a valuable team player and does offer and receive help to and from, sometimes unexpected, places and people.

One example of the above is the work of Otto Scharmer at the Massachusetts Institute of Technology (MIT). ${ }^{23}$ Space does not allow to give an introduction to his work except to say that his institute helps the business world and other organisations to deal with the profound global transformation process. One 21. https://en.wikipedia.org/wiki/Pope_Benedict_xvi

22.https://en.wikipedia.org/wiki/Pope_Francis

23.http://mitsloan.mit.edu/faculty-and-research/faculty-directory/detail/?id=41401 Also: http://www.ottoscharmer.com/ There is a huge amount of internet information on his work and theories. 


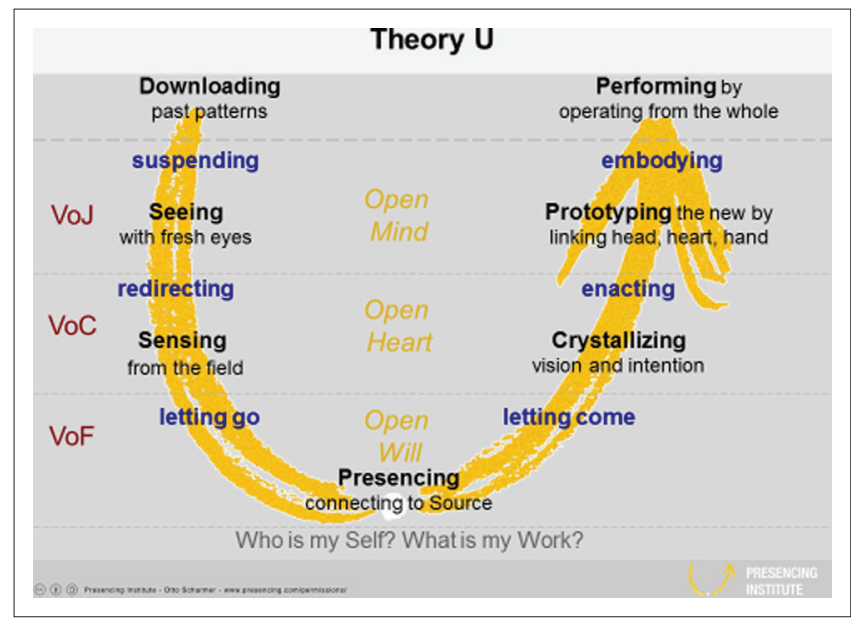

Source: Scharmer, C.O., 2009, Theory U: Leading from the future as it emerges: The socia technology of presencing, Berret-Koehler, San Francisco, CA

FIGURE 1: Theory U.

interesting aspect of this help is that it is strongly value based, working with concepts that Christians immediately recognise. Not surprising, then, Scharmer's methodology and approach is widely used in churches (Venter 2010; Venter \& Hendriks 2012). I will use one of his presentations as an example of how different his methodology compares and differs from to the situation in the previous cycle (Scharmer 2009:246). ${ }^{24}$

With reference to Figure 1, a short explanation using a biblical hermeneutic will have to suffice. VoJ, VoC and VoF refer to the voices of judgement, cynicism and fear that confront a person or institution to open their mind, heart and will to transformation. Instead of downloading past patterns, one has to suspend them, redirect and let go of those patterns in order to see with fresh eyes and to sense (observe, imagination, discernment) the way forward. This is doing theology as life goes on, when the process proceeds from a biblical or missional identity and from being open to the guidance of the Holy Spirit to discern what God reveals, to act upon it and to embody it. Scripture stays central in this process (see 'Dwelling in the Word' referred to above), but not fundamentalistically bound by or caught in either dogma or ideology. It simply is a discipline that tries to lead one on an Abrahamic journey of discovery of true identity, a mission and a promised land.

\section{Final conclusion}

Transformation is part of life. Taking our cue from Mary, theology is about following Jesus as life on this planet goes on. One learns a lot about life by heeding the lessons provided by previous stages of the journey. Currently, we are awakening to the lesson we learned that there is no such thing as absolute knowledge, knowledge one can control with whatever rationality or logic at our command. We are at a place where we are forced to humble ourselves and to rediscover what it means to be made in the image of God and what it means to be here to serve as Jesus did, self-sacrificing, kenosis-style.
The examples given at the beginning of this article served to illustrate how new movements of the Spirit (ALICT, TWNAF) sprout forth from the periphery (Walls 2002:32), where people are open to do 'presencing' (connecting to the deepest source, from which the future begins to take shape viewing from the source, Scharmer 2009:39). The Presbyterian group referred to phrased their initial questions in the terminology of the outgoing system (cycle) and against the backdrop of upholding their institution at all costs. However, the probationers were truly enthusiastic and inspired by Tickle, Castells and Scharmer and there is no doubting their willingness to commit to a journey of transformation. The plight of small rural congregations highlights the difficulties accompanying transformation and a lack of adequate leadership to do so. The story of Stellenbosch Gemeente helps to illustrate a number of typical challenges on the journey to transformation - amongst others the role of leadership. To begin with, if a congregation cannot curtail the voices of judgement, cynicism and fear (as in Scharmer's scheme) that are required to open the mind, heart and will, then it will not set out on the journey. Also, once you are on the journey, empowering and serving leadership are essential to help, what Friedman called 'uploading', take place (see 'Introduction: On transformation' section). If one uses Castells' terminology, this means one has to allow new networks to form and one has to realise that identity formation in a missio Dei-style is the only one that allows for the imago Dei to develop. SG illustrates how a congregation tries to shape its ministry according to what Scharmer calls presencing, trying to gravitate away from institutionalism through deliberate operational changes that focus on producing intentional communities.

One last question remains and it is one that this essay did not answer: To which extent do our theological institutions, indeed theology as a discipline, succeed in entering vernacular culture and interacting with it? Our theological institutions (faculties) stand in a tradition that emanates from the 16th century and still reveals that ethos, one of a previous cycle. The way teaching staff are institutionally rewarded (note the surge for National Research Foundation accreditation) also reflects an old paradigm. Bosch prophesied that we should do theology as life goes on, that is, with the marginalised, from below, with the poor. Is our setting helping us in this regard? Are we in contact, in community, with the emerging world and church?

A good way to end this essay is perhaps a challenge posed by a well-known contemporary South African practical theologian who intuitively follows her sister Mary in doing theology as life goes on, struggling to find the way in a new time and age. Denise Ackermann's After the locusts, letters from a landscape of faith (2003) and Surprised by the man on the borrowed donkey ... (2014) seem to call for involvement in the vernacular culture, interacting with it, translating it. We are challenged to journey with her and others who do theology as life goes on. We need to do it with our students, not to proselytise them into being becoming academics, but simply to try and follow Jesus with them. 


\section{Acknowledgements Competing interests}

The author declares that he has no financial or personal relationships which may have inappropriately influenced him in writing this article.

\section{References}

Ackermann, D.M., 2003, After the locusts: Letters from a landscape of faith, Eerdmans, Grand Rapids, MI.

Ackermann, D.M., 2014, Surprised by the man on the borrowed donkey; ordinary blessings, Lux Verbi, Cape Town.

Adedibu, B., 2009, Storytelling, an effective communication appeal in preaching, Choir, Gloucester.

Adedibu, B., 2012, Coat of many colours; the origin, growth, distinctiveness and contributions of black majority Churches to British Christianity, Choir, Gloucester.

Algemene Sinode, 2013, Raamwerkdokument oor die missionale aard en roeping van die kerk, viewed 5 October 2016, http://www.kerkargief.co.za/doks/acta/AS Agenda_2013.pdf

Bax, D.S., 2013, 'The witness of the Presbyterian Church of Southern Africa, 1960-1990', in M.-A

Plaatjies-Van Huffel \& R. Vosloo (eds.), Reformed Churches in South Africa and the struggle for justice, pp. 143-169, Sun Media, Stellenbosch.

Bons-Storm, R., 1987, Geloof waardig; stappen op de weg van gemeenteopbouw, Boekencentrum B.V, 's-Gravenhage.

Bosch, D., 1991, Transforming mission, Orbis, New York.

Carstens, C., 2014, The world needs a father; a trainer's guide, Paarl Media, Paarl.

Castells, M., 1996, The rise of the network society: The information age: Economy, society and culture, vol. I, Blackwell, Oxford.

Castells, M., 2000, End of millennium: The information age: Economy, society and culture, vol. III, 2nd edn., Blackwell, Oxford.

Castells, M., 2004, The power of identity: The information age: Economy, society and culture, vol. II, 2nd edn., Blackwell, Oxford.

Castells, M., 2015, Networks of outrage and hope; social movements in the interne age, 2nd edn., Polity, Cambridge.

Cox, H., 1995, Fire from heaven: The rise of Pentecostal spirituality and the reshaping of religion in the twenty-first century, Addison-Wesley, New York.

De Gruchy, J.W., 2004, The church struggle in South Africa, SCM, London.

Dennison, J., 1999, City reaching: On the road to community transformation, William Carey Library, Pasadena, CA.

Du Plooy, A.J., 2013, 'Die ontwikkeling van 'n missionale ekklesiologie en leierskap in klein plattelandse gemeentes', MTh tesis, Departement Praktiese Teologie en Missiologie, Universiteit van Stellenbosch.

Dulles, A., 1985, Models of the church, Gill \& MacMillan, London.

Du Toit, D., 2014, Jaap Durand praat oor eenheid, versoening en geregtigheid, Bybelkor, Wellington.

Ellison, P.T., 2009, 'Word-dwelling, deep listening, and faith-based moral conversation in congregations: A nested vision for learning new habits', in P. Keifert (ed.) Testing the spirits: How theology informs the study of congregations, pp. 91-108, Testing the spirits: How theology
Eerdmans, Grand Rapids, MI.

Friedman, T.L., 2007, The world is flat: A brief history of the twenty-first century, updated and expanded, Picador, New York.

Giddens, A., 2002, Runaway world: How globalization is reshaping our lives, new edn., Profile, London.

Goedhart, G.L., 1984, Gemeenteopbouw, om dienende, vierende, lerende en delende gemeente te worden, Kok, Kampen.

Gorman, M.J., 2009, Inhabitating the cruciform God, kenosis, justification and theosis in Paul's narrative soteriology, Eerdmans, Grand Rapids, MI.

Guder, D.L. (ed.), 1998, Missional church: A vision for the sending of the church in North America, Eerdmans, Grand Rapids, MI.

Handelinge Algemene Sinode, 2011, 'Daar is baie literatuur oor klein gemeentes waarvan ' $\mathrm{n}$ lys verskyn in die verslag oor klein gemeentes wat in Okt 2011 voor die Algemene Sinode gedien het', viewed September 2016, from http://kleingemeentes.co.za/wp-content/uploads/as2011verslag/verslaghttp://kleingemeentes.co.
kleingemeentes-as2011.pdf

Heitink, G., 1999, Practical theology: History, theory, action domains, Eerdmans, Grand Rapids, Ml.

Hendriks, H.J., 1992, Strategiese beplanning in die gemeente, Hugenote, Wellington.

Hendriks, H.J., 2009, 'Trauma and conflict as prerequisites for identity transformation Lessons from the South African Partnership for Missional Churches', Dutch Reformed Theological Journal 50 (1\&2), 109-119.
Hendriks, H.J., 2012, 'Die toekoms van die klein plattelandse gemeente', HTS Teologiese Studies/Theological Studies 68(2), 1-8. https://doi.org/10.4102/hts. v68i2.1287

Hendriks, H.J. \& Erasmus, J.C., 2005, 'Religion in South Africa: The 2001 population census data', Journal of Theology for Southern Africa 121, 88-111.

Jenkins, P., 2002, The next Christendom: The coming of global Christianity, Oxford University Press, Oxford.

Jenkins, P., 2006, The new faces of Christianity: Believing the Bible in the global South, Oxford University Press, Oxford.

Keifert, P., 2006, We are here now: A new missional era, Allelon, Eagle, Idaho.

Kinghorn, J. (red), 1986, Die NG Kerk en apartheid, Macmillan, Johannesburg.

Marais, F., 2007, God praat - leef luisterryk vir vergaderings: Handleiding vir gemeenteleiers op soek na God se agenda vir gemeentes, Bybelkor, Wellington.

Marais, F., 2010, Meeting with God's voice. A guide for leaders seeking God's agenda for their congregation, Bible Media, Wellington.

McGavran, D.A., 1980, Understanding church growth, rev. ed., Eerdmans, Grand Rapids, MI.

McLaren, B.D., 2000, The church on the other side: Doing ministry in the postmodern matrix, Zondervan, Grand Rapids, MI.

McLaren, B.D., 2007, Everything must change: Jesus, global crisis, and a revolution of hope, Thomas Nelson, Nashville, TN.

Mead, L.B., 1991, The once and future church, Alban, Washington, DC.

Mead, L.B., 1994, Transforming congregations for the future, Alban, Washington, DC.

Mead, L.B., 1996, Five challenges for the once and future church, Alban, Washington, DC.

Mocke, C.J., 1994, "n Identiteitsanalise van die Ned Geref Gemeente Nieuwoudtville', MTh tesis, Departement Praktiese Teologie en Missiologie, Universiteit van Stellenbosch.

Moore, R., 2002, Starting a new church: The church planter's guide to success, Regal, Ventura, CA.

Naude, P.J., 2010, Neither clock nor calender; perspectives on the Belhar Confession, Eerdmans, Grand Rapids, MI.

Nel, M., 1994, Gemeentebou, Orion, Halfway House.

Nel, M.J., 2013, 'The influence of dwelling in the Word within the Southern African Partnership of Missional Churches', Verbum et Ecclesia 34(1), Art. \#778, 1-7. https://doi.org/10.4102/ve.v34i1.778

Niemandt, C.J.P., 2010, 'Five years of missional church: Reflectyions on missional ecclesiology', Missionalia 38(3), 397-412.

Niemandt, N., 2007, Nuwe drome vir nuwe werklikhede, Lux Verbi, Wellington.

Niemandt, N., 2013, Nuwe leiers vir nuwe werklikhede, CUM, Vereeniging.

Peens, H., 2011, 'Implikasies van 'n missionale transformasieproses vir die NG Gemeente Marken se voortbestaan', MTh tesis, Departement Praktiese Teologie en Missiologie, Universiteit van Stellenbosch, viewed September 2016, from http://scholar.sun.ac.za/handle/10019.1/6629

Piketty, T., 2014, Capital in the twenty-first century, Belknap Press of Harvard University Press, Cambridge MA.

Ring van Stellenbosch, 1997a, Notule 16 Maart 1998. NGK in SA Argief KR 851.

Ring van Stellenbosch, 1997b, Notule 7 Sept 1997. NGK in SA Argief KR 851.

Scharmer, C.O., 2009, Theory U: Leading from the future as it emerges: The socia technology of presencing, Berret-Koehler, San Francisco, CA.

Schwarz, C.A. \& Schwarz, F., 1984, Theologie des Gemeinde-aufbaus: Ein Versuch, Aussaat Verlag, Neukirchen-Vluyn.

Sheridan, T.M. \& Hendriks, H.J., 2013, 'The missional Church movement', Dutch Reformed Theological Journal, NGTT 54(3\&4), viewed September 2016, from http://ngtt.journals.ac.za/pub/article/view/402

Stark, R., 1997, The rise of Christianity, Harper Collins, San Francisco, CA.

Steuernagel, V.R., 2003, 'Doing theology with an eye on Mary', Evangelical Review of Theology 27(2), 100-112.

Sweet, L., 2000, Post-modern pilgrims: First century passion for the 21st century world, Broadman, Nashville, TN.

Tickle, P., 2008, The great emergence: How Christianity is changing and why, Baker, Grand Rapids, MI.

Tickle, P., 2012, Emergence Christianity: What it is, where it is going and why it matters, Baker, Grand Rapids, MI.

Van Zyl, J.D.W., 2008, 'Van vasgelooptheid na hoop. 'n Deskriptiewe studie van die samesmelting tussen die NG Studentekerk en Moederkerk op Stellenbosch', Ongepubliseerde MTh tesis, Departement Praktiese Teologie en Missiologie, Ongepubliseerde MTh tesis,

Venter, L. \& Hendriks, H.J., 2012, 'Geloofsonderskeiding - moontlikhede van 'n interdissiplinêre reis', NGTT 53(1\&2), 232-247, viewed September 2016, from http://ngtt.journals.ac.za

Venter, L.J., 2010, Dans met Triniteit, MTh tesis, Departement Praktiese Teologie en Missiologie, Universiteit van Stellenbosch, viewed September 2016, from http:// hdl.handle.net/10019.1/5355

Walls, A.F., 2002, The cross-cultural process in Christian history, Orbis, Maryknoll, NY. 